\title{
A Review of Interactional Competence Assessment in the Saudi EFL Context
}

\author{
Najla Abdulrahman AlQahtani ${ }^{1 \& 2}$ \\ ${ }^{1}$ College of Languages and Translation, King Khalid University, Saudi Arabia \\ ${ }^{2}$ College of Sciences and Humanities, Prince Sattam bin AbdulAziz University, Saudi Arabia \\ Correspondence: Najla Abdulrahman AlQahtani, PhD Candidate, College of Languages and Translation, King \\ Khalid University, Saudi Arabia. E-mail: na.alqahtani@psau.edu.sa
}

\author{
Received: August 30, $2021 \quad$ Accepted: October 8, $2021 \quad$ Online Published: October 22, 2021 \\ doi:10.5539/ijel.v11n6p28 URL: https://doi.org/10.5539/ijel.v11n6p28
}

\begin{abstract}
Interactional competence (IC) lies at the heart of the communicative skills an EFL learner is supposed to master. This paper investigates the meanings, assessment methods, and implications of IC in a second/foreign language setting and particularly in the Saudi context. The first part charts a theoretical background to the study of language from the early debate of the notions of competence and performance, through the evolution of communicative competence and the emergence of the term interactional competence. The second part of the paper outlines how IC has been described in the literature from multiple perspectives; interactional patterns, resources and strategies, IC authenticity, raters' interpretations of IC and finally how the term was used in the Saudi context. However, it was aimed through this paper to draw an advantageous picture that provides a comprehensive understanding to how the term interactional competence has been taken up in the field of second/foreign language assessment. Needless to say, IC assessment is still an under-researched field in Saudi Arabia, and needs further efforts from the teachers, researchers and policy makers to provide thorough insights into assessing and employing interactional skills in the Saudi EFL classrooms.
\end{abstract}

Keywords: communicative skills, EFL, interactional competence, language assessment

\section{Introduction}

Communicative skills are essential in learning a foreign language and they are fundamental objectives of teaching and learning English as a foreign language. Learning a new language sheds light on the presupposition of the nature of language (Harris, 1981; Heller, 2007). Graham (2007) asserted that students in foreign language learning have expressed that being able to communicate orally is the ultimate goal. Canale and Swain (1980) subcategorized communicative competence into four main competencies: linguistic competence (knowledge of linguistic forms), sociolinguistic competence (the ability to use language appropriately in contexts), discourse competence (coherence and cohesion), and strategic competence (knowledge of verbal and non-verbal communication strategies). Recently, this theory has been rejected and interactional competence has been suggested instead.

In her seminal work on interactional competence (IC), Kramsch (1986) was the first to coin the term interactional competence to caption the dynamic process of communication. In addition, Galaczi and Taylor (2018) have also defined it as "L2 learners' ability to co-construct interaction in a purposeful and meaningful way, taking into account socio-cultural and pragmatic dimensions of the speech situation" (p. 8). According to Hall and Doehler (2011), interactional competence reflects "the knowledge of communication rules and the use of linguistic and interactional resources within a specific context by two interlocutors who engage in a dynamic, reciprocal process of co-constructing L2 spoken interaction" (p. 4). In fact, IC can be regarded as the use of required linguistic and interactional resources (e.g., turn-taking and task-related management) to contribute to the context-specific conversation.

According to Hall (2018) who investigated the emergence of the term interactional competence in SLA, this concept existed around the same time in two different fields: linguistic anthropology and sociology. Moreover, she asserted that in each field it was employed for a different meaning. According to her, the source of interactional competence "as used in studies of L2 learning in the field of linguistic anthropology and in 
particular in the work of Dell Hymes" (p. 26). Firstly, Hymes $(1962,1964)$ posited a theory of language in response to the theory of language proposed by Noam Chomsky $(1957,1966)$ who postulated that linguistic competence refers to the rules any speaker of a language knows implicitly; language according to him was a fixed, universal property of the human mind containing a set of abstract principles, common across all languages, from which language-specific syntactic rules were generated (Chomsky, 1966). Conversely, communicative competence was coined by Hymes to refer to the individual capacity to acquire and employ this social knowledge in various social contexts. Hence, Hymes regarded Chomsky's view of competence to be insufficient in that it could not account for the social knowledge that is essential for individuals' understanding and employment of language.

At about the same time that Hymes was developing his theory of communicative competence, Harvey Sacks and his colleagues, Emanuel Schegloff and Gail Jefferson, were working on a theory of social action that resulted in what is known as conversation analysis (CA). Sacks (1992), followed Chomsky's approach in the way it accounted for a universal competence, yet while Chomsky's interest in competence was in its abstract system of generative rules of language, Sacks was interested in the basic, universal techniques by which social life is arranged. Additionally, instead of a theorized competence premised on intuition, Sacks was concerned with the actual, publicly witnessable, common sense knowledge, i.e., an interactional competence (Maynard, 2012; Sacks, 1992). Hutchby and Wooffitt (2008) stated that "competence is a value-laden construct in education and perhaps in a wide range of workplace environments more broadly, where an individual can be located on an assessment rubric as more or less competent" (p. 60). Accordingly, they demonstrated that such a view of competence contradicted the emphasis of conversation analysis on describing, rather than evaluating, and the techniques and procedures adopted by participants in order to understand each other and make themselves understood as well.

Waring (2018) noted that the concept of interactional competence (IC) in applied linguistics lacks clarity in terms of the precise constituents of such competence. Part of the controversy of the term "competence" is attributed to its association as the opposite of Chomsky's performance, which is the actual usage of language. In addition, Waring (2018) clarified that the idea of interactional competence is grounded in different intellectual habits that stress both changeability and universality to produce more confounding descriptions of what it implies. A greater specification of such a concept is required in order to benefit from such theoretical arguments in actual teaching. Furthermore, a promising venue proposed by Waring (2018) is to shift the debate from interactional competence to its visible incarnation such as the practices of turn-taking, sequencing, overall structuring and repair. Furthermore, Waring noted that a small number of studies were conducted to tackle the issue of assessing interactional competence more or less directly; much of the work was devoted to pragmatics competence. For instance, Young (2015) equated pragmatic competence in interaction with interactional competence and was able to establish some standards for assessing such competence including content delivery, language use, sensitivity to the situation, and turn organization. Moreover, Ikeda (2017) in her study for the assessment instrument for L2 pragmatics performance in university settings, also equated discourse-oriented L2 pragmatic ability as interactional competence.

In her distinguished publication, Hall (2018) proposed the term interactional repertoires "as a more empirically useful term to refer to the objects of L2 learning" (p. 26). While some researchers called for reconsidering the notion of IC, Hall suggested replacing the concept of IC with interactional repertoires. She argued that it is beneficial to apply this term as it reflects the changing nature of the various resources that learners employ and develop in their own contexts which accordingly can reinforce the studies of L2 learning as well as second language acquisition.

Clearly, while scholars struggled to identify the exact meaning and components of IC, practitioners such as teachers and exam raters struggled with assessing L2 IC. In fact, language assessments and practices are among the most significant arenas to comprehend language competence. Clearly, our understanding of the field of IC assessment is just "partial if not rudimentary" says Waring (2018, p. 60). He even argued that a problem exists in measuring IC constituents and in establishing standards. However, content knowledge and language proficiency were the major focus of researchers in terms of assessing their second/foreign language as shall be seen in the next section.

\section{Literature Review}

\subsection{Interactional Patterns, Resources, and Strategies}

The term interactional patterns refer to the types of interaction (collaborative and asymmetric) interlocutors create in a conversation from two aspects of a conversation: mutuality and equality. On the one hand, mutuality is related to how interlocutors engage in the conversation and contribute to making meaning. On the other hand, equality is 
concerned with the way the conversation is well managed and distributed between them (Van Lier, 1996). Interactional patterns were defined in English as a second language (ESL) written discourse as collaborative, dominant/passive, expert/novice, and dominant/dominant (Storch, 2002). In the oral discourse perspective, a discourse-based study on test-takers' interaction in a paired speaking test (PST) by Galaczi (2008) revealed four interactional patterns. A collaborative pattern is one in which interlocutors cooperate and extend their own voice and their partner's and it is characterized by a high level of mutuality and equality. The other pattern is the parallel pattern, which involves interlocutors developing their own topics, but they do not extend each other's. In addition, if the course of conversation manifests imbalance because one of the pairs is dominant and the other is passive, it will be the asymmetric pattern. Lastly, the blend pattern occurs when the interlocutors concurrently construct two different patterns within the same conversation.

A study conducted by Artunç and Hart (2019) at a Turkish state university, was aimed at exploring the degree to which using interactional resources such as taking turns or managing a task, as well as the interactional patterns of EFL learners in paired speaking tests (PSTs) once EFL examinees who had the same vs. different levels of proficiency were combined together. The findings of this study clearly suggested that interactional competence was measured best when two high-level examinees are matched together as opposed to low-high level test takers. Likewise, Niederauer (2014) investigated the use of communication strategies in face-to-face interaction of the Celpe-Bras Exam. The results revealed that the employed strategies do not provide the optimum capacity of these interactional resources. Furthermore, inconsistencies were evident with regard to proficiency levels and the use of communication strategies during the interview for the assessment of oral proficiency.

A recent co-teaching study in a foreign language classroom by Alcalà et al. (2020) was conducted to measure the consequences of an experience by four teachers to analyze whether co-teaching and using Classroom Interactional Competence (CIC) tactics nurture the quality of L2 interactional competence. The findings of this study manifested that co-teaching is beneficial for both teachers and students because of the professional growth teachers can gain whereas students can obtain more attention and security, and consequently they can produce more L2 output. Obviously, the use of various conversational strategies in the ESL/EFL classroom will ensure more understanding and will contribute to promote student involvement and participation.

\subsection{IC Authenticity}

Ensuring the authenticity of interactional tasks is one of the challenging issues in language assessment. Various studies have been conducted to reveal the complexities of such procedures. Paired speaking tests (PSTs) are considered more valid and authentic as opposed to individual interviews; as Brooks (2009) argued paired testing is more authentic because it further reflects the students' oral interaction types and the sort of classroom commonly used speaking tasks. Oral interviews on the other hand can reflect an asymmetric interactional pattern with "unequal rights and responsibilities between the examiner and test-taker" (Galaczi \& Taylor, 2018, p. 4).

Lam's (2015) study was intended to explore whether the group interaction task, in the way it is implemented, elicits authentic oral language use in a school-based speaking assessment (SBA) in Hong Kong. It aimed to assert the significance of flexibility and sensitivity to students' needs in its implementation. Data were collected via students' discourse in the assessed interactions, stimulated recall with students and teachers, and a mock assessment. It was shown through the test discourse that there were some features that likely suggest interaction authenticity, yet it has questionable authenticity of engagement by students. Moreover, a closer look at students' pre-task planning activities detected the artificial interaction. Hence, it was concluded that "what can be observed in the SBA assessed interactions is often not students' in situ execution of interactional competence in L2, but a 'canned' product of students' execution of the competence prior to the assessed interaction in L1 during pre-task planning" (Lam, 2015, p. 8). This study suggested significant recommendations to be considered for the assessment methods on task implementation. Preparation time can be given to students to allow for adequate brainstorming of ideas and language vocabulary, rather than pre-scripting the interaction, which can only be permitted at the initial stages of the upper-secondary curriculum in order to elicit spontaneous interaction in the graded assessments.

\subsection{Raters' Interpretations of IC}

It has been detected in previous literature that different research methodologies have been employed to explore IC in order to approach an inclusive description of the construct. One of these methods was to explore raters' interpretation of IC during paired or group oral exams. Furthermore, such studies will enrich the field in terms of the development of rating scales, materials, and guidelines. Undoubtedly, raters' understanding of assessment criteria for IC is an essential aspect of testing and assessing IC. The context of assessment can definitely offer us some insights into how IC is conceptualized in association with specific conduct. May's (2009) research of the 
perspectives of trained raters towards interaction in a paired speaking test contributed to raising awareness of the significance of this aspect in IC assessment. She noted that raters included irrelevant items such as test-takers' body language and social behaviors in their ratings, which verifies and the urgent need for clear descriptors to guide the raters.

Ducasse and Brown (2009) used verbal protocol analysis to collect data from 12 teachers who examined 17 paired speaking tests of a Spanish beginner-level course at an Australian university. Results had three parameters: namely non-verbal interpersonal communication, interactive listening, and interactional management skills. Additionally, a study by Orr (2002) investigated raters' perspectives of IC in Cambridge English speaking tests. The study referred to diverse facets that were not stated in the rating criteria, namely, non-verbal communication and comparison feedback of candidates' performances. Similarly, May (2011) reported on notable IC features of four raters who assessed 12 paired speaking candidates in an English for Academic Purposes (EAP) university context. It was observed in this study that interaction was performed through mutual achievement. A recent study by Borger (2019), investigated qualitatively the features of IC in a paired speaking test from raters' perceptions in a Swedish national test of English as a Foreign Language (EFL). Using the Common European Framework of Reference for Languages (CEFR) scales, 17 EFL teachers from Sweden and 14 raters from Finland and Spain rated six audio-recorded paired performances and submitted their written feedback to interpret their scores and account for prominent features. Findings from this study revealed three interactional resources: topic development moves, turn-taking management, and interactive listening strategies. The interactional role of test-takers was also reported by the raters. Another study by Sandlund and Sundqvist (2019) targeted raters' perceptions of learners' IC in Sweden. The findings from this study indicated that an 'examination of raters' interaction in assessment can reveal weaknesses in scoring criteria that leave too much room for interpretation, and as such, rater interactions also serve as important sources of information for the development of tests and assessment criteria on IC" (p. 37). This affirms the fact that tasks and rating rubrics must be concise enough to create the sorts of interaction and rater interpretations that the construct is designed to capture.

\subsection{IC Assessment in the Saudi Context}

Compared to the rapid growth of IC assessment studies in ESL contexts over the past decades, less attention has been devoted to this topic in the EFL counterpart. Moreover, no specific reference to the Saudi context was found. However, most of the studies that have examined this context were conducted from different perspectives, such as IC development, usage, sources, and features. Al-wossabi (2016) highlighted that studies of interactional competence of conversations are still under-researched in the Saudi EFL classroom. He described the current situation of teaching in Saudi Arabia as teacher-dominated where students are merely passive receptors of knowledge. To this end, he conducted a study to explore the importance of involving Saudi EFL students in the process of understanding the flow and structure of spontaneous and interactive conversation via following a conversation analysis (CA) approach. The findings suggested raising learners' awareness of the interactional functions in the native speakers' speech in real life contexts before examining a particular pragmatic and interactional function in learners' discourse as "learners would rather value learning a second language through observed features of natural behaviors rather than specified parameters of teacher and learners talk in class analysis" (p. 40). It was noted throughout this study that interactional practices must be vital components of the EFL curriculum in Saudi Arabia if we are to improve Saudi students. Al-wossabi further proposed that the application of CA in Saudi EFL classrooms is not an easy task but rather a dramatic change for both teachers and students from "how language is prescribed in textbooks to how it is actually used in native speakers' talk" (p. 40).

Another study by Jawhar (2018) showed how the appropriate use of L1 as a source of humour yielded an immense amount of interaction from Saudi students at a language institute. She investigated the effect of "the teachers' competent use of the first language (L1) as a source of humour on classroom interaction and, consequently, learning" via using the micro-analytical approach of conversation analysis (CA). Furthermore, she confirmed that this approach provided a friendly atmosphere and raised interactional competence in the classroom. It is worth noting that the students manifested their interactional competence and grasp of the "interactional routine by obtaining the teachers' attention verbally and non-verbally, taking unsolicited turns and initiating humour" (p. 307). Such interactional features are substantial components of IC as Young (1999) stated. The findings have, indeed, shed light on an overlooked aspect of interactional practices, which will induce the low achiever to get involved in the classroom without the fear of losing face.

\section{Conclusion}

The foregoing discussion has provided a summarized background to the notion of IC and the ways it has been interpreted and employed by various scholars. The literature review of IC in second/foreign language contexts was 
referred to in order to indicate, in more concrete terms, the processes and constituents of IC. Moreover, it was aimed throughout this paper to draw an advantageous picture that provides a comprehensive understanding of how the term interactional competence has been taken up in the field of second/foreign language assessment. However, it is not possible to tackle all aspects and issues pertaining to IC assessment in this paper. Needless to say, IC assessment as shown above is still under-researched in the Saudi context and needs further effort from teachers, researchers, and policymakers to bridge the existing gap in the literature. A major shift in the teaching methodology should take place in the Saudi EFL classrooms, as Al-wossabi (2016) highlighted that in order to prepare Saudi EFL students to communicate successfully with the interconnected world, interactional tasks must be vital components of the Saudi EFL speaking curriculum.

Undoubtedly, IC studies in Saudi classrooms will lead the way to improving more sustainable solutions before the contemporary challenges of EFL pedagogy. Thus, it is recommended for researchers to carry out further studies on IC assessment in the Saudi context and to investigate the various approaches and modes to best assess it. Finally, this review highlighted a major pedagogical implication which is the lack of IC studies in Saudi Arabia as well as the necessity to further explore the various interactional tasks which involves written, oral and online communications.

\section{References}

Al-wossabi, S. (2016). A Conversational Analysis Model for Promoting Practices of Interactional Competence in the EFL Context. International Journal of English Linguistics, 6(6). https://doi.org/10.5539/ijel.v6n6p32

Alcalà, E., Comallonga, L., Sala, M., \& Galera, M. (2020). Co-teaching to Foster Classroom Interactional Competence (CIC): How Can Co-teaching Benefit Classroom Interactional Competence? CLIL. Journal of Innovation and Research in Plurilingual and Pluricultural Education, 3(1), 35-36. https://doi.org/10.5565/rev/clil.31

Artunç, E., \& Hart, D. (2019). Interactional competence in paired speaking tests: A study on proficiency-based pairings. System, 89, 194-102. https://doi.org/10.1016/j.system.2019.102194

Borger, L. (2019). Assessing interactional skills in a paired speaking test. Apples - Journal of Applied Language Studies, 13(1), 151-174. https://doi.org/10.17011/apples/urn.201903011694

Brooks, L. (2009). Interacting in pairs in a test of oral proficiency: Co-constructing a better performance. Language Testing, 26(3), 341-366. https://doi.org/10.1177/0265532209104666

Canale, M., \& Swain, M. (1980). Theoretical Bases of Communicative Approaches to Second Language Teaching and Testing. Applied Linguistics, 1(1), 1-47. https://doi.org/10.1093/applin/I.1.1

Chomsky, N. (1957). Syntactic Structures. The Hague: Mouton. https://doi.org/10.1515/9783112316009

Chomsky, N. (1966). Topics in the Theory of Generative Grammar. The Hague: Mouton.

Ducasse, A. M., \& Brown, A. (2009). Assessing paired orals: Raters' orientation to interaction. Language Testing, 26(3), 423-443. https://doi.org/10.1177/0265532209104669

Galaczi, E. (2008). Peer-peer interaction in a speaking test: The case of the first certificate in English examination. Language Assessment Quarterly, 5(2), 89-119. https://doi.org/10.1080/15434300801934702.

Galaczi, E., \& Taylor, L. (2018). Interactional competence: Conceptualizations, operationalisations, and outstanding questions. Language Assessment Quarterly, 15(3), 219-236. https://doi.org/10.1080/15434303.2018.1453816

Graham, S. (2007). Developing Speaking Skills in the Modern Foreign Language, Practical Guide to Teaching Modern Foreign Language in the Secondary School. Oxon: Routledge

Hall, J. K. (2018). From L2 interactional competence to L2 interactional repertoires: Reconceptualising the objects of L2 learning. Classroom Discourse, 9(1), 25-39. https://doi.org/10.1080/19463014.2018.1433050

Hall, J. K., \& Doehler, S. P. (2011). L2 interactional competence and development. In L2 Interactional Competence and Development (pp. 1-18). Bristol: Multilingual Matters. https://doi.org/10.21832/9781847694072-003

Harris, R. (1981). The Language Myth. London: Duckworth.

Heller, M. (2007). Bilingualism as ideology and practice. New York: Palgrave. https://doi.org/10.1057/9780230596047_1

Hutchby, I., \& Wooffitt, R. (2008). Conversation Analysis (2nd ed.). Malden, MA: Polity Press. 
Hymes, D. (1972). On Communicative Competence. Sociolinguistics, 8(3), 269-293. Harmondsworth: Penguin.

Ikeda, N. (2017). Measuring L2 Oral Pragmatic Abilities for Use in Social Contexts: Development and Validation of an Assessment Instrument for L2 Pragmatics Performance in University Settings. Unpublished doctoral diss. The University of Melbourne.

Jawhar, S. S. (2018). The use of L1 as a Source of Humour to Facilitate Interaction in EFL Classrooms. Arab World English Journal, 9(3), 294-310. https://doi.org/10.24093/awej/vol9no3.20

Kasper, G., \& Youn, S. J. (2017). Transforming Instruction to Activity: Roleplay in Language Assessment. Applied Linguistics Review, 5(1), 13-20.

Kramsch, C. (1986). From language proficiency to interactional competence. The Modern Language Journal, 70(4), 366-372. https://doi.org/10.1111/j.1540-4781.1986.tb05291.x

Lam, D. M. K. (2015). Contriving authentic interaction: Task implementation and engagement in school-based speaking assessment in Hong Kong. In G. Yu \& Y. Jin (Eds.), Assessing Chinese learners of English: Language constructs, consequences and conundrums (pp. 38-60). Basingstoke: Palgrave Macmillan. Reproduced with permission of Palgrave Macmillan. https://doi.org/10.1057/9781137449788_3

May, L. (2009). Co-constructed interaction in a paired speaking test: The rater's perspective. Language Testing, 26(3), 397-421. https://doi.org/10.1177/0265532209104668

May, L. (2011). Interactional competence in a paired speaking test: Features salient to raters. Language Assessment Quarterly, 8(2), 127-145. https://doi.org/10.1080/15434303.2011.565845

Maynard, D. (2012). Everyone and no One to Turn to: Intellectual Roots and Contexts for Conversation Analysis. The Handbook of Conversation Analysis, 1(2), 11-31. Oxford: Wiley-Blackwell. https://doi.org/10.1002/9781118325001.ch2

Niederauer, M. (2014). Competência interacional: critério para avaliação da produção oral em língua adicional. Trabalhos em Linguística Aplicada, 53(2), 403-424. https://doi.org/10.1590/S0103-18132014000200008

Orr, M. (2002). The FCE Speaking test: Using rater reports to help interpret test scores. System, 30(2), 143-154. https://doi.org/10.1016/S0346-251X(02)00002-7

Sacks, H. (1992). Lectures on Conversation (Vol. 1 \& 2). Oxford: Blackwell.

Sandlund, E., \& Sundqvist, P. (2019). Doing versus assessing interactional competence: Contrasting L2 test interaction and teachers' collaborative grading of a paired speaking test. In Teaching and Testing L2 Interactional Competence: Bridging Theory and Practice (pp. 357-396). Oxon and New York: Routledge. https://doi.org/10.4324/9781315177021-14

Storch, N. (2002). Patterns of interaction in ESL pair work. Language Learning, 52(1), 13-30. https://doi.org/10.1111/1467-9922.00179

Van Lier, L. (1996). Interaction in the language curriculum: Awareness, autonomy and authenticity. London: Longman. https://doi.org/10.4324/9781315843223

Waring, H. Z. (2018). Teaching L2 interactional competence: Problems and possibilities. Classroom Discourse, 9(1), 57-67. https://doi.org/10.1080/19463014.2018.1434082

Youn, S. J. (2015). Validity Argument for Assessing L2 Pragmatics in Interaction Using Mixed Methods. Language Testing, 32(2), 199-225. https://doi.org/10.1177/0265532214557113

Young, R. (1999). Sociolinguistic approaches to SLA. Annual, 19, 105-132. https://doi.org/10.1017/S0267190599190068

\section{Copyrights}

Copyright for this article is retained by the author, with first publication rights granted to the journal.

This is an open-access article distributed under the terms and conditions of the Creative Commons Attribution license (http://creativecommons.org/licenses/by/4.0/). 